\title{
Registered Nurses Perceptions of the Transferability of New Graduate Registered Nurses Skills across Healthcare Settings
}

\author{
Bev Mackay, Thomas Harding \\ NorthTec Nursing Department, Whangarei, New Zealand \\ Email: bmackay@northtec.ac.nz, tharding@northtec.ac.nz
}

How to cite this paper: Mackay, B. and Harding, T. (2019) Registered Nurses Perceptions of the Transferability of New Graduate Registered Nurses Skills across Healthcare Settings. Open Journal of Nursing, 9, 1088-1105.

https://doi.org/10.4236/ojn.2019.910080

Received: August 6, 2019

Accepted: October 28, 2019

Published: October 31, 2019

Copyright () 2019 by author(s) and Scientific Research Publishing Inc. This work is licensed under the Creative Commons Attribution International License (CC BY 4.0).

http://creativecommons.org/licenses/by/4.0/

\begin{abstract}
Aims and Objectives: This paper describes Registered Nurses' (RN's) perceptions of the transferability of New Graduate Registered Nurses (NGRN's) skills across settings: one aspect of a larger study exploring RN's perceptions of NGRN's work-readiness. Background: There is evidence RN's do not consider NGRN's as adequately prepared for practice. However, there does not appear to be consensus on what characterizes work-readiness. Methods: An adapted online questionnaire was sent to RNs in a range of clinical settings. They rated NGRNs' skills and the applicability of those skills to their clinical setting using a 5-point Likert scale. Results: Perceptions of transferability of skills across settings varied. In the skills grouping of routine assessment, basic clinical skills, advanced clinical skills the percentage rated as "not applicable" was over $40 \%$ in $75 \%$ of the skills. The low or zero non-applicable responses to communication skills indicate this skill group contains transferable skills regardless of the setting. The zero non-applicable responses for preparedness for practice for all but two skills indicate these groups contain transferable skills across settings. Conclusion: There appears to be some alignment between expectations from RNs and current NGRN preparation. The lack of transferability of more advanced technical skills raises questions about the role of education in preparing the NGRN versus that of industry-based graduate programmes. The increase in nursing roles and the increased emphasis on aged care and primary health care dictates that generalist preparation of NGRNs emphasising the attributes of an RN should be the focus rather competency in advanced technical skills.
\end{abstract}

\section{Keywords}

New Registered Nurse Graduates (NGRN's), Work-Readiness, Clinical Skills, Questionnaire 


\section{Introduction}

Over the last two decades concerns about the adequacy of nursing programmes to prepare work-ready graduates have been widely reported in the international nursing literature [1]. In the local context of Northland, New Zealand anecdotal evidence, such as discussions between education and the clinical providers at clinical contract meetings, suggest that Registered Nurses (RNs) have mixed perceptions about the work readiness of new graduate registered nurses (NGRNs). Additionally, there appears to be no overall consensus with respect to the particular skills in which the NGRN should be competent.

A large mixed-method study using exploratory sequential design was undertaken by Missen et al. [1] [2] [3] in Victoria, Australia investigating the work readiness of NGRNs. Phase 2 of this study [1] examined the perceptions of qualified nurses (including Enrolled Nurses) about NGRN's preparedness in a range of technical and non-technical skills. These included: routine assessment; basic and advanced clinical skills; medication administration; emergency procedures; communication skills; preparedness for practice; and coping with work environment. This paper reports the findings of a study in Northland, New Zealand (NZ) related to transferability of skills across settings which is one aspect of a larger project which replicated the research of Missen et al. [1]. The intention of the larger study was to provide evidence of any key concerns around competency so nurse educators from the local education provider and local employers including the District Health Board could better prepare NGRN's to be ready for work.

\section{Background}

Bakon et al. [4] report the increasing global concern that NGRNs are under pressure to transition quickly from the student role in a health care environment that is highly stressed. The reasons for an increasingly stressed healthcare environment and the impact on NGRNs have been documented elsewhere in the literature [5]. Certainly, over the last several decades some key stressors in the healthcare environment and the delivery of nursing care have been the increased use of technology, higher numbers of admissions with increased acuity, and an ageing population and increasing prevalence of chronic disease [1]. These trends, along with an ageing nursing workforce and a predicted global shortage of nurses [6], highlight the importance of NGRN's being able to quickly transition into the workforce and competently perform the requisite clinical skills. Although there is limited research in the New Zealand setting with respect to the work readiness of new graduates, being underprepared has been reported by many NGRN's themselves. A research pilot of new graduate first year of clinical practice nursing programme found that only one third of NGRNs felt confident at commencement of the programme [7].

A requisite for rapid transition must be adequate preparation; however, there is considerable evidence internationally that nurses do not perceive their new graduate nursing colleagues as adequately prepared for practice [1] [8] [9] [10] 
[11] [12]. However, a precondition must also be a shared understanding of what constitutes and a work-ready graduate and what is not evident in the literature is consensus with respect to identifying the requisite clinical skills for a new graduate and to what extent they should be transferable across the different nursing settings.

The paper that follows presents an overview of the key findings related to nurses' perceptions of new graduates' work readiness and highlights the variance in views about what are the key new graduate clinical skills across a range of healthcare environments.

\section{Methods}

This study utilised a descriptive quantitative design using an online questionnaire originally developed in Victoria, Australia based on perceptions of Graduate Nurse Programme Co-ordinators of the new graduate experience [3]. This was then developed into a questionnaire to elicit registered nurses perceptions on the work readiness of NGRNs [1].

Following approval from the developers, the questionnaire was adapted for the NZ context. The changes to the questionnaire involved alterations to the wording and the list of skills. For example, gaining patient/ family feedback regarding culturally safe care was added to the communication skills category. Several skills in the original version were removed; for example, providing leadership to colleagues as this was considered beyond the scope of new graduates. Additions were made to emphasise the importance of Nursing Council of New Zealand (NCNZ) competencies, ethics and relevant legislations [13]. These included: seeks evidence to demonstrate achievement of Nursing Council competencies, managing when there is an ethical dilemma; knowledge and application of legislation (Mental Health Act, Health Practitioners' Competence Assurance Act); applying the Codes (Code of Conduct, Patient Rights, Health Information Privacy Code) and demonstrating nursing that is supported by a sound knowledge base.

The original Australian survey was applied in hospital settings whereas this adapted survey also included community settings. The rating of "not applicable" was therefore extended to all skills to reflect the expanded settings, as not all the skills listed may be required in each setting. Content validity was achieved by obtaining feedback from nurse academics, nurse leaders and educators in community organisations, iwi providers, the private sector, hospitals, aged care and mental health. The final version administered comprised of 66, 5-point Likert-type responses asking RNs to rate NGRNs' skills.

Ethics approval was gained from the NorthTec Ethics Committee. All requirements with respect to consent, confidentially and Treaty of Waitangi processes were met. Cultural input was obtained from an experienced Māori nursing researcher who acted as cultural advisor. The research report was made available to all participants in the research. 
A purposive sample of registered nurses engaged in practice in the Northland region of New Zealand at the time of the study were invited to participate. Recruitment was facilitated through the distribution lists of key organisations employing nurses in the region. The nurse managers who received the emails were asked to disseminate the information about the survey-explanation of the study and the link to the online questionnaire-to the RNs in their organisation. Additionally, one of the researchers attended nurse educator and nurse leader meetings to talk about the study and promote its uptake from as wide a pool of RNs as possible. Potential participants were informed that the study involved completion of a 20-minute anonymous questionnaire about their views on the practice readiness of NGRNs on commencement of their first year of practice in the clinical setting. Consent was inferred through completion and submission of the questionnaire.

\section{Results}

The data obtained from the questionnaires were analysed using an excel statistics package. As per the approach used by Missen et al. [1] ordinal data is presented with numbers and frequencies with medians (range of 1 - 5) and interquartile ranges. To promote readability the Likert-type items are presented in collapsed form (3 instead of 5) amalgamating "very good" and "good" and "poor" and "very poor".

Sixty-four questionnaires were completed. All participants completed Part One (Likert-type questions) but only $75 \%$ completed Part Two (demographic information). The demographic characteristics of the participants are summarised in Table 1. The majority of participants were female (94\%). Of the 64 participants $20 \%$ were 34 years of age or less and $20 \%$ were aged over 55 years; the rest (59\%) were between 35 and 54 years. The majority (67\%) had undertaken their nursing education in the Polytechnic sector with $23 \%$ educated in the hospital setting and $10 \%$ within a university setting. Seventy-five percent had undertaken their nursing education in New Zealand and $82 \%$ were undertaking or had undertaken postgraduate studies.

The participants rated the NGRNs' abilities on entry to the clinical setting for 66 clinical skills subdivided by the following categories: 1) Routine Assessment; 2) Basic Clinical Skills; 3) Advanced Clinical Skills; 4) Medication Administration; 5) Emergency Procedures; and 6) Communication Skills. Additionally, they were also asked to rate their preparedness in terms of preparedness for practice and coping with the work environment.

A breakdown of "not applicable responses" was undertaken to compare across community, hospital and aged care settings. There was variability in transferability of skills across different settings (community, aged care and acute hospital) depending on their skill groups with the largest number of "not applicable" being recorded in the "advanced skills category" (Table 2). Across the three skill groupings in Table 2 (routine assessment, basic clinical skills, advanced clinical 
Table 1. Demographic data for sample $(n=64)$.

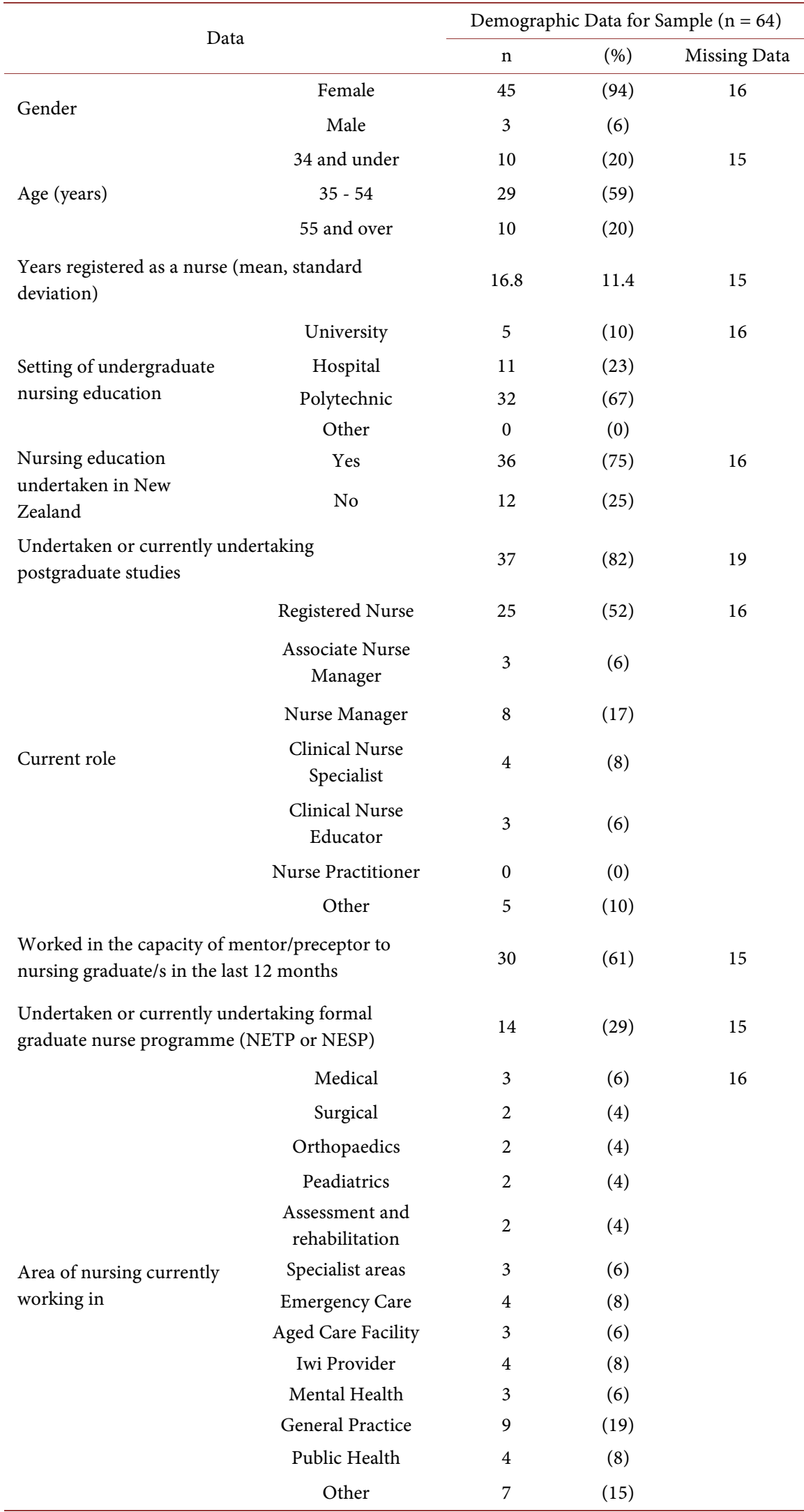

a. NETP, Nurse Entry to Practice Programme; NESP, New Entry to Specialist Practice Programme. 
Table 2. Non applicable responses $(n=64)$ assessment, basic and advanced clinical skills.

\begin{tabular}{|c|c|c|c|c|c|c|}
\hline \multirow[b]{2}{*}{ Group of Skills } & \multicolumn{6}{|c|}{ Non Applicable Responses Assessment, Basic and Advanced Clinical Skills } \\
\hline & N/A & $\begin{array}{l}\text { Missing } \\
\text { Data }\end{array}$ & Community & Hospital & Aged Care & Not Identified \\
\hline \multicolumn{7}{|l|}{ Routine Assessment } \\
\hline $\begin{array}{l}\text { Undertaking suicide } \\
\text { risk assessment }\end{array}$ & $31 \%(20)$ & 0 & 5 & 8 & 2 & 5 \\
\hline $\begin{array}{l}\text { Undertaking mental } \\
\text { status assessments } \\
\text { using appropriate } \\
\text { tool (BATOMI) }\end{array}$ & $21 \%(13)$ & 1 & 4 & 4 & 1 & 4 \\
\hline $\begin{array}{l}\text { Undertaking } \\
\text { assessments } \\
\text { specific to areas } \\
\text { (EWS, PEWS) }\end{array}$ & $17 \%(11)$ & 0 & 3 & 1 & 2 & 5 \\
\hline $\begin{array}{l}\text { Undertaking } \\
\text { general risk } \\
\text { assessment } \\
\text { (eg falls risk) }\end{array}$ & $8 \%(5)$ & 0 & 3 & 0 & 0 & 2 \\
\hline $\begin{array}{l}\text { Undertaking } \\
\text { psychosocial/ } \\
\text { spiritual assessment }\end{array}$ & $6 \%(4)$ & 0 & 0 & 2 & 0 & 2 \\
\hline $\begin{array}{l}\text { Undertaking } \\
\text { primary initial } \\
\text { assessments }\end{array}$ & $5 \%(3)$ & 0 & 0 & 1 & 0 & 2 \\
\hline $\begin{array}{l}\text { Undertaking } \\
\text { focused assessments } \\
\text { (using inspection, } \\
\text { palpitation, } \\
\text { percussion, } \\
\text { auscultation skills) }\end{array}$ & $5 \%(3)$ & 0 & 0 & 1 & 0 & 2 \\
\hline $\begin{array}{l}\text { Undertaking } \\
\text { secondary } \\
\text { assessments } \\
\text { (head to toe) }\end{array}$ & $3 \%(2)$ & 1 & 0 & 1 & 0 & 1 \\
\hline $\begin{array}{l}\text { Identifying normal } \\
\text { and abnormal } \\
\text { assessment results }\end{array}$ & $3 \%(2)$ & 3 & 0 & 0 & 0 & 2 \\
\hline $\begin{array}{l}\text { Manually taking } \\
\text { vital signs }\end{array}$ & $2 \%(1)$ & 0 & 0 & 0 & 0 & 1 \\
\hline $\begin{array}{l}\text { Developing and } \\
\text { implementing } \\
\text { nursing care based } \\
\text { on assessment data }\end{array}$ & $2 \%(1)$ & 1 & 0 & 0 & 0 & 1 \\
\hline $\begin{array}{l}\text { Recording, reporting } \\
\text { and documenting }\end{array}$ & $2 \%(1)$ & 0 & 0 & 0 & 0 & 1 \\
\hline
\end{tabular}




\section{Continued}

\section{Basic Clinical Skills}

\section{Managing}

pre and

post-operative

$39 \%(24) \quad 3$

9

6

care

\section{Administering}

and monitoring

blood

$34 \%(22)$

5

8

4

1

transfusions

Administering

intravenous

$33 \%(20)$

$+2$

infusions

Planning for

discharge in a

26\% (15)

3

4

5

3

8

timely manner

Assisting patients

with activities of

daily living (eg

feeding,

$17 \%(10) \quad 4$

6

6

1

3

5

ambulation,

personal hygiene)

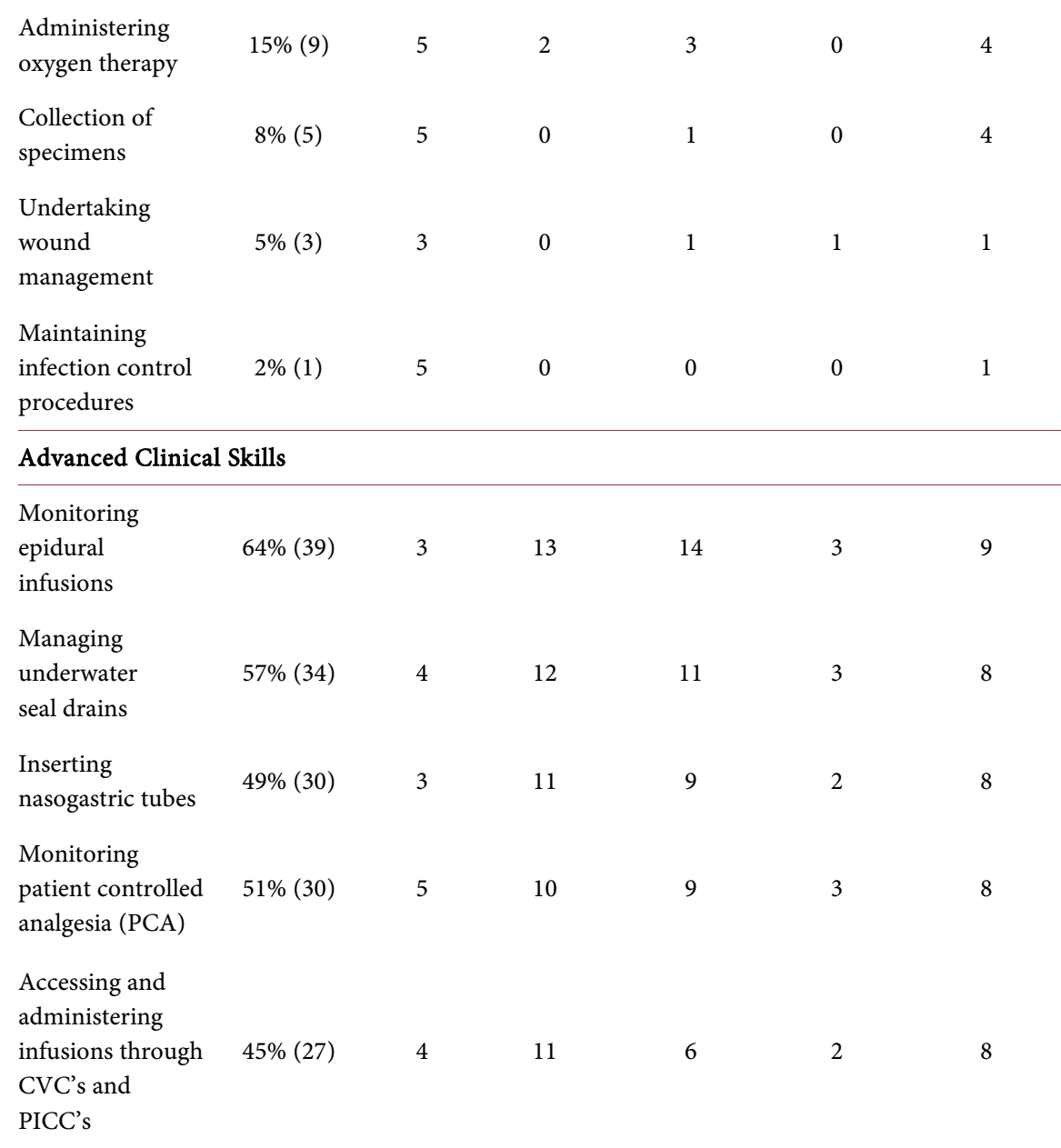




\section{Continued}

\begin{tabular}{|c|c|c|c|c|c|c|}
\hline $\begin{array}{l}\text { Inserting } \\
\text { indwelling } \\
\text { urinary catheters }\end{array}$ & $43 \%(26)$ & 4 & 10 & 8 & 1 & 7 \\
\hline $\begin{array}{l}\text { Delivery of } \\
\text { calming and } \\
\text { restraint } \\
\text { techniques when } \\
\text { appropriate }\end{array}$ & $29 \%(17)$ & 6 & 8 & 4 & 0 & 5 \\
\hline $\begin{array}{l}\text { Interpreting } \\
\text { ECG's }\end{array}$ & $23 \%(14)$ & 3 & 3 & 3 & 2 & 6 \\
\hline
\end{tabular}

a. Median is calculated out of 5 ( 1 = very poor, 5 = very good); IQR, Interquartile range; N/A, not applicable; BATOMI, Behaviour, Affect, Thought form, content, Orientation, Mood, Insight; EWS, Early warning signs; PEWS, Paediatric early warning signs; ECGs, electrocardiographs; CVC, Central Venous Catheter, PICC, Peripherally inserted Central Catheter.

skills) the percentage of respondents rating skills as "not applicable" was higher than $40 \%$ in $75 \%$ of the listed skills, indicating that those skills were not deemed relevant to these clinical settings and indicating lack of transferability across settings. From Table 2 it can be seen that "suicide risk assessment was viewed by many as "not applicable" (31\%) closely followed by "mental status assessment? The latter was across all the settings: community, aged care and acute hospital".

Table 3 presents the non-applicable responses for the skills groupings "medication administration", "emergency procedures" and "communication". Nonapplicable choices for medication administration indicate a degree of transferability although there are obvious skills which do not transfer well, for example, administering intravenous medication (see Table 3). The non-applicable responses for the skills in the "emergency procedures" grouping were mixed but appear to have some transferability depending on the actual skill and setting involved. The low or zero non-applicable responses to communication skills indicate that this skill group contains transferable skills regardless of the setting.

The zero non-applicable responses for preparedness for practice for all but two skills-caring for full patient load and working independently-indicate that these groups contain transferable skills regardless of the setting although there was quite a large amount of missing data (see Table 4). Non applicability ranges with the skills group of "coping with the work environment" were mixed and obviously had some transferability depending on the actual skill and the setting involved.

\section{Discussion}

The aim of the larger study was to explore the perceptions of RNs on the practice readiness of NGRNs. In their original report [14], it was found that the more technical the skill is, the fewer participants perceived that they were adequately performed or applicable to their practice settings.

The results reported here (Tables 2-4) indicate that there is perceived 
Table 3. Non applicable responses $(n=64)$ medication and emergency procedures.

\begin{tabular}{|c|c|c|c|c|c|c|}
\hline \multirow{2}{*}{ Group of Skills } & \multicolumn{6}{|c|}{ Non Applicable Responses $(n=64)$ Medication and Emergency Procedures } \\
\hline & N/A & Missing Data & Community & Hospital & Aged Care & Not Identified \\
\hline \multicolumn{7}{|c|}{ Medication Administration } \\
\hline $\begin{array}{l}\text { Administering } \\
\text { intravenous } \\
\text { medications }\end{array}$ & $33 \%(20)$ & 3 & 5 & 5 & 3 & 7 \\
\hline $\begin{array}{l}\text { Calculating the } \\
\text { right drug dosages }\end{array}$ & $10 \%(6)$ & 3 & 1 & 2 & 1 & 2 \\
\hline $\begin{array}{l}\text { Adhering to the } \\
\text { eight rights when } \\
\text { administering } \\
\text { medications }\end{array}$ & $8 \%(5)$ & 3 & 2 & 2 & 0 & 1 \\
\hline $\begin{array}{l}\text { Understanding the } \\
\text { physiological } \\
\text { responses to the } \\
\text { medication } \\
\text { administered }\end{array}$ & $5 \%(3)$ & 3 & 1 & 1 & 0 & 1 \\
\hline $\begin{array}{l}\text { Administering } \\
\text { subcutaneous and } \\
\text { intramuscular } \\
\text { injections }\end{array}$ & $5 \%(3)$ & 6 & 0 & 1 & 0 & 2 \\
\hline $\begin{array}{l}\text { Medication } \\
\text { knowledge, knowing } \\
\text { the common } \\
\text { medications used }\end{array}$ & $2 \%(1)$ & 3 & 0 & 0 & 0 & 1 \\
\hline \multicolumn{7}{|c|}{ Emergency Procedures } \\
\hline $\begin{array}{l}\text { Administering } \\
\text { basic life support }\end{array}$ & $23 \%(14)$ & 3 & 4 & 3 & 3 & 4 \\
\hline $\begin{array}{l}\text { Understanding } \\
\text { and following } \\
\text { call/code } \\
\text { procedures }\end{array}$ & $14 \%(8)$ & 5 & 5 & 0 & 1 & 2 \\
\hline $\begin{array}{l}\text { Recognising } \\
\text { patients that } \\
\text { are deteriorating } \\
\text { and acting } \\
\text { appropriately }\end{array}$ & $7 \%(4)$ & 3 & 0 & 2 & 0 & 2 \\
\hline \multicolumn{7}{|c|}{ Communication Skills } \\
\hline $\begin{array}{l}\text { Communicating } \\
\text { utilising } \\
\text { appropriate } \\
\text { communication } \\
\text { tool (eg SBAR) }\end{array}$ & $8 \%(5)$ & 5 & 4 & 1 & 0 & 0 \\
\hline $\begin{array}{l}\text { Formally handing } \\
\text { over patients in } \\
\text { their care }\end{array}$ & $5 \%(3)$ & 4 & 2 & 1 & 0 & 0 \\
\hline
\end{tabular}




\section{Continued}

\begin{tabular}{|c|c|c|c|c|c|c|}
\hline $\begin{array}{l}\text { Providing } \\
\text { opportunistic } \\
\text { health promotion } \\
\text { and health } \\
\text { education }\end{array}$ & $2 \%(1)$ & 4 & 0 & 0 & 1 & 0 \\
\hline $\begin{array}{l}\text { Communicating } \\
\text { with Managers/ } \\
\text { senior personnel }\end{array}$ & $0 \%(0)$ & 4 & 0 & 0 & 0 & 0 \\
\hline $\begin{array}{l}\text { Interacting with } \\
\text { other health care } \\
\text { team members }\end{array}$ & $0 \%(0)$ & 5 & 0 & 0 & 0 & 0 \\
\hline $\begin{array}{l}\text { Documenting } \\
\text { patient progress } \\
\text { in patient notes } \\
\text { utilising setting } \\
\text { specific tool if } \\
\text { appropriate (eg } \\
\text { SOAPIE) }\end{array}$ & $0 \%(0)$ & 5 & 0 & 0 & 0 & 0 \\
\hline $\begin{array}{l}\text { Interacting with } \\
\text { patients/families/ } \\
\text { whanau/ } \\
\text { significant others }\end{array}$ & $0 \%(0)$ & 4 & 0 & 0 & 0 & 0 \\
\hline $\begin{array}{l}\text { Gaining } \\
\text { patient/family/ } \\
\text { whanau feedback } \\
\text { regarding } \\
\text { culturally safe } \\
\text { care delivery }\end{array}$ & $0 \%(0)$ & 4 & 0 & 0 & 0 & 0 \\
\hline $\begin{array}{l}\text { Communicating } \\
\text { patient changes } \\
\text { and new } \\
\text { information to } \\
\text { colleagues in a } \\
\text { timely fashion }\end{array}$ & $0 \%(0)$ & 4 & 0 & 0 & 0 & 0 \\
\hline
\end{tabular}

a. Median is calculated out of 5 ( 1 = very poor, 5 = very good $)$; IQR, Interquartile range; N/A, not applicable; BATOMI, Behaviour, Affect, Thought form, content, Orientation, Mood, Insight; EWS, Early warning signs; PEWS, Paediatric early warning signs; ECGs, electrocardiographs; CVC, Central Venous Catheter, PICC, Peripherally inserted Central Catheter.

variability in transferability of skills across different settings (community, aged care and acute hospital) depending on their skill grouping. Advanced skills scored most highly in the non-applicable rating (45\%) which is to be expected as the majority are setting specific. This was followed by basic clinical skills (20\%) indicating lack of transferability across settings for these categories. Non applicability responses with the skills groups of "emergency procedures" (Table 3) and "coping with the work environment" (Table 4) were mixed and obviously had some transferability depending on the actual skill and the setting involved. Non-applicable choices for routine assessment (8.7\%) and medication administration (10.5\%) also indicate a degree of transferability although there are 
Table 4. Non applicable responses $(n=64)$ preparedness for practice and coping with the work environment.

\begin{tabular}{|c|c|c|c|c|c|c|}
\hline \multirow{2}{*}{ Group of Skills } & \multicolumn{6}{|c|}{$\begin{array}{l}\text { Non Applicable Responses }(n=64) \text { Preparedness for } \\
\text { Practice and Coping with the Work Environment }\end{array}$} \\
\hline & N/A & $\begin{array}{c}\text { Missing } \\
\text { Data }\end{array}$ & Community & Hospital & $\begin{array}{l}\text { Aged } \\
\text { Care }\end{array}$ & $\begin{array}{c}\text { Not } \\
\text { Identified }\end{array}$ \\
\hline \multicolumn{7}{|c|}{ Preparedness for Practice } \\
\hline $\begin{array}{l}\text { Caring for full } \\
\text { patient load }\end{array}$ & $4 \%(3)$ & 10 & 3 & 0 & 0 & 0 \\
\hline $\begin{array}{l}\text { Working } \\
\text { independently }\end{array}$ & $4 \%(3)$ & 10 & 3 & 0 & 0 & 0 \\
\hline $\begin{array}{l}\text { Working as part } \\
\text { of the team }\end{array}$ & $0 \%(0)$ & 10 & 0 & 0 & 0 & 0 \\
\hline $\begin{array}{l}\text { Working appropriately } \\
\text { in terms of time } \\
\text { management }\end{array}$ & $0 \%(0)$ & 10 & 0 & 0 & 0 & 0 \\
\hline $\begin{array}{l}\text { Ability to critically } \\
\text { think and problem } \\
\text { solve }\end{array}$ & $0 \%(0)$ & 10 & 0 & 0 & 0 & 0 \\
\hline $\begin{array}{l}\text { Utilising } \\
\text { organisational policies } \\
\text { and guidelines }\end{array}$ & $0 \%(0)$ & 10 & 0 & 0 & 0 & 0 \\
\hline $\begin{array}{l}\text { Maintaining duty of } \\
\text { care, confidentiality } \\
\text { and privacy }\end{array}$ & $0 \%(0)$ & 10 & 0 & 0 & 0 & 0 \\
\hline $\begin{array}{l}\text { Displaying } \\
\text { professionalism in } \\
\text { their role as a nurse }\end{array}$ & $0 \%(0)$ & 10 & 0 & 0 & 0 & 0 \\
\hline $\begin{array}{l}\text { Applying the codes } \\
\text { (Code of Conduct, } \\
\text { Patient rights, Health } \\
\text { Information Privacy } \\
\text { Code) }\end{array}$ & $0 \%(0)$ & 10 & 0 & 0 & 0 & 0 \\
\hline $\begin{array}{l}\text { Knowledge and } \\
\text { application of } \\
\text { legislation (eg Mental } \\
\text { Health Act, Health } \\
\text { Practitioners } \\
\text { Competence } \\
\text { Assurance Act) }\end{array}$ & $4 \%(3)$ & 10 & 2 & 0 & 1 & 0 \\
\hline $\begin{array}{l}\text { Maintaining safe } \\
\text { work practices }\end{array}$ & $0 \%(0)$ & 10 & 0 & 0 & 0 & 0 \\
\hline $\begin{array}{l}\text { Demonstrating } \\
\text { nursing practice that is } \\
\text { supported by sound } \\
\text { knowledge base }\end{array}$ & $0 \%(0)$ & 10 & 0 & 0 & 0 & 0 \\
\hline
\end{tabular}




\section{Continued}

\begin{tabular}{|c|c|c|c|c|c|c|}
\hline $\begin{array}{l}\text { Seeks evidence to } \\
\text { demonstrate } \\
\text { achievement of } \\
\text { Nursing Council } \\
\text { competencies }\end{array}$ & $1 \%(1)$ & 10 & 1 & 0 & 0 & 0 \\
\hline $\begin{array}{l}\text { Managing when there } \\
\text { is an ethical dilemma }\end{array}$ & $4 \%(3)$ & 10 & 2 & 1 & 0 & 0 \\
\hline \multicolumn{7}{|c|}{ Coping with the Work Environment } \\
\hline $\begin{array}{l}\text { Working in charge on } \\
\text { shifts as } \\
\text { required-setting } \\
\text { appropriate (eg Aged } \\
\text { Care) }\end{array}$ & $61 \%(31)$ & 13 & 12 & 15 & 0 & 4 \\
\hline $\begin{array}{l}\text { Maintaining own } \\
\text { safety when working } \\
\text { within community } \\
\text { settings }\end{array}$ & $38 \%(20)$ & 11 & 6 & 12 & 2 & 0 \\
\hline $\begin{array}{l}\text { Coping with night } \\
\text { shifts }\end{array}$ & $26 \%(14)$ & 10 & 11 & 1 & 0 & 2 \\
\hline $\begin{array}{l}\text { Coping with shift } \\
\text { changes }\end{array}$ & $17 \%(9)$ & 10 & 7 & 1 & 0 & 1 \\
\hline $\begin{array}{l}\text { Understanding the } \\
\text { rostering process }\end{array}$ & $6 \%(3)$ & 12 & 2 & 0 & 0 & 1 \\
\hline
\end{tabular}

a. N/A, not applicable.

obvious skills which do not transfer well because they are setting specific, for example, "administering intravenous medication". The low or zero non-applicable responses to communication skills $(1.6 \%)$ and preparedness for practice $(0 \%)$ indicate that these groups contain transferable skills regardless of the setting.

The results presented here raise concern about participants' perceptions of skills not being applicable to their practice setting when there are those which should in fact be applicable across settings. The NCNZ (2010) [13] requires undergraduate nursing programmes to prepare students for comprehensive health consumer assessment skills. The results of this study indicate that skills around mental health (suicide risk assessment, "mental status assessment" and "delivery of calming \& restraint techniques") are either viewed as not applicable or that students are only adequately or poorly prepared. This is a concern when suicide rates are increasing [15]. According to Davison, Mackay and McGivern [16], New Zealand nurses are at the forefront of health services and are well placed to conduct suicide risk assessment within many settings and undergraduate programmes have a responsibility to prepare nursing students for this life saving skill. Therefore it is disappointing to note that such a high percentage of respondents' viewed this skill and that of mental status assessment as not applicable to their setting.

There appears to be some alignment between expectations from RNs in clini- 
cal areas on expectations of clinical skills of NGRNs and the current preparation of NGRNs particularly with respect to "communication skills" and "preparation for practice" being seen as applicable across all settings. However, the lack of transferability of more advanced technical skills raises the question of the role of the education provider in preparing the NGRN and the role of the industry-based graduate programme. There are many challenges for NGRNs in their first year of practice but perhaps the biggest, and largely unacknowledged challenge, is that they are caught in the tension between industry and education with respect to how of NGRNs should be prepared for entry into practice [1] [10] [17] [18]. Education and industry are influenced by different system drivers. On the one hand industry is requiring NGRNs to perform in the role of the RN in the setting in which they are employed, versus the education requirement to prepare a generalist nurse who is able to function at a competent level regardless of the setting [10] [18].

Although there is acceptance of the place of the first year in practice in developing confidence and competence within the clinical setting the reality is that often acuity levels and staff shortages negatively impact on support for NGRNs [19]. Both this study and the study by Missen et al. [1] demonstrated that registered nurses perceive that NGRNs are not prepared for advanced skills. The question must be raised of the expectation of advanced skills on entry to practice. It needs to be questioned whether these should be expected on entry to practice or whether these should be introduced in the first year of practice. According to El Haddad et al. [10], there needs to be more collaboration between industry and education providers to develop a shared understanding of the expectations of NGRN's in regard to readiness for practice.

In the past, most new graduate programmes were based in a hospital setting [7]. However, it is apparent that there is a shift from the dominance of secondary services towards a greater emphasis on community services with an associated requirement for more nurses including NGRNs and undergraduate programmes should prepare them for these settings [20] [21] [22]. There is now potential for extension into the community with NETPE and NESP programmes [23], but opportunities are still limited [24].

Current competency in New Zealand is assessed in undergraduate education and in nursing practice against the NCNZ competencies. There is also an expectation from NCNZ [13] of demonstration of competency across all settings, evidenced in the requirement that students experience a range of settings in preparation for entry to practice; including: primary health care and community settings, acute care including medical and surgical settings, continuing care settings including rehabilitation/disability care settings and mental health care including acute and rehabilitation/continuing care settings (p. 62).

In addition, students are required to meet $\mathrm{RN}$ domains of practice before entry to practice. These include: professional responsibility, provision of nursing care, interpersonal relationships and inter-professional healthcare and quality 
improvement. A range of competencies and indicators support the attainment of these domains. These competencies and indicators do not identify explicit technology-based clinical or advanced skills, apart from around information. Specifically the Council [13] requires that nursing schools prepare students to a graduate level by demonstration of: pharmacology knowledge and medicine management, comprehensive health consumer assessment skills and clinical decision-making skills, therapeutic communication with health consumers, working within a health care team; providing direction and delegation in practice and in the use of information technology and health information management. ( $p$. 60)

An alignment between NCNZ competencies and clinical skills would be useful to support clarity in a review of clinical skills within the undergraduate curriculum. The findings of this study with respect to the positive perceptions of RN participants toward NGRN preparation in the skill groups of communication and preparation for practice and the transferability of these skills across settings validate the importance of these skill groups, at least, in forming a foundation for the first year of practice.

\section{Implications for Practice}

It is apparent that the increase in nursing roles and the increased emphasis on aged care and primary health care [22] [23] dictates that generalist preparation of NGRNs should be the focus rather than preparation in setting specific or with competency in advanced technical skills. The future of nursing is changing in response to increasing demand for technology and in complexity, therefore, we need to prepare nurses for lifelong nursing. According to the World Health Organisation [25]:

Education standards should ensure that education programmes prepare graduates who are capable of critical thinking and problem-solving, and capable of functioning as competent, ethical care providers. In addition the educational experience should promote the capacity to become a self-directed, life-long learner (p. 7).

In response to this demand, there is increasing literature arguing for preparing NGRN's according to the attributes of a registered nurse rather than skill preparation [17], and the importance of non-technical or "soft" skills and their impact on clinical performance [26]. According to Laker and Powell [27], "soft" skills are those relating to intrapersonal and interpersonal skills whereas hard skills are "the technical expertise and knowledge needed for a job" (p. 453) [28]. There is also a third category, that of cognitive skills which Robles [28] deems just as important as soft skills. Some sort of balance between these sets of skills is required within curricula.

The professional confidence of NGRNs on entry to the workforce impacts on their readiness to practice [29]. The disconnect between the clinical and undergraduate nursing environment is one factor in the influence on confidence. Re- 
ality shock has been well covered in the literature and is a very real phenomenon in an increasingly complex health environment [30] [31]. Preparing students for reality shock in undergraduate education is essential and developing professional confidence is a process that needs to carry on in the first year of practice, but could be expedited through strategies for preparation for entry to practice in undergraduate education [29]. These include a focus on soft skills such as interpersonal interaction and communication which could be achieved through simulation or from an emphasis on this in clinical settings (with clinical teaching support). Additionally, Baldwin et al. [17] also suggest that the graduate attributes of nursing students include: "Resilient, reflective, resolute, reliability, resourceful, confident, contemporary, communicative, courageous, compassionate, competent, robust" (p. 10) and that curricula should be designed to allow development of these attributes.

If we are to have work-ready practitioners for the future in a health care that is increasingly dynamic and complex then there needs to be better alignment between the goals of education and practice. In order to enhance the support for NGRNs a necessary first step must be collaboration between the two groups to develop shared understanding of expectations of NGRN's preparation across all settings and a move toward establishing a consensus with respect to the skills competency which would characterise a work-ready NGRN. This would then provide the foundation for education in the clinical setting for RNs to better understand what NGRN skills and their transferability of skills across settings.

\section{Limitations}

This study represents the findings from one small regional study, therefore, the results cannot be generalised and it is also likely that the results represent the views of those nurses within clinical practice most interested in new graduates. However, many of the findings support the results of previous research in Victoria, Australia indicating that there is some potential for transferability of these findings to other regions in New Zealand and Australia.

\section{Conclusion}

This study explored the perceptions of RNs on the practice readiness of NGRNs and, in particular, perceptions with respect to the transferability of skills across practice settings. It is evident that some skills-mainly those at the non-technical end of the spectrum-are viewed as transferable. The results raise concerns with respect to the number of participants who do not consider skills relating to mental health being applicable to their practice setting. Additionally, questions are raised about the current clinical skills within extant curricula and which would actually characterise a work-ready graduate. It may be beneficial to categorise skills into soft, hard and cognitive and align these against Nursing Council competencies. Collaboration is required between education providers and practice to develop a shared understanding across settings of the expectations of 
NGRN readiness to practice.

\section{Acknowledgements}

The authors would like to acknowledge Norma Scobie for her work on this project.

\section{Conflicts of Interest}

The authors declare no conflicts of interest regarding the publication of this paper.

\section{References}

[1] Missen, K., McKenna, L., Beauchamp, A. and Larkins, J.A. (2016) Registered Nurses' Rate New Nursing Graduates as Lacking Skills in Key Clinical Areas. Journal of Clinical Nursing, 25, 2134-2143. https://doi.org/10.1111/jocn.13316

[2] Missen, K., McKenna, L. and Beauchamp, A. (2014) Role Adaptation Experienced by Nursing Graduates in Their First Year of Practice. A Descriptive Qualitative Approach. Journal of Nursing Education and Practice, 4, 134-141. https://doi.org/10.5430/jnep.v4n12p134

[3] Missen, K., McKenna, L. and Beauchamp, A. (2015) Work Readiness of Nursing Graduates: Current Perspectives of Graduate Nurse Program Coordinators. Contemporary Nurse, 51, 27-38. https://doi.org/10.1080/10376178.2015.1095054

[4] Bakon, S., Craft, J., Wirihana, L., Christensen, M., Barr, J. and Tsai, L. (2018) An Integrative Review of Graduate Transition Programmes: Developmental Considerations for Nursing Management. Nurse Education in Practice, 28, 80-85. https://doi.org/10.1016/j.nepr.2017.10.009

[5] Hegarty, J., Walsh, E., Condon, C. and Sweeney, J. (2009) The Undergraduate Education of Nurses: Looking to the Future. International Journal of Nursing Education Scholarship, 6, 6-11. https://doi.org/10.2202/1548-923X.1684

[6] Gellasch, P. (2015) The Driving Forces behind Nurses Leaving the Profession. Nurse Leader, 13, 63-68. https://doi.org/10.1016/j.mnl.2015.01.001

[7] Ministry of Health (2004) New Graduate First Year of Clinical Practice Nursing Programme: Evaluation Report. Ministry of Health, Wellington.

[8] Adlam, K., Dotchin, M. and Hayward, S. (2009) Nursing First Year of Practice, Past, Present and Future: Documenting the Journey in New Zealand. Journal of Nursing Management, 17, 570-575. https://doi.org/10.1111/j.1365-2834.2008.00932.x

[9] Brown, R.A. and Crookes, P.A. (2016) What Level of Competency Do Experienced Nurses Expect from a Newly Graduated Registered Nurse? Results of an Australian Modified Delphi Study. BMC Nursing, 15, 45.

https://doi.org/10.1186/s12912-016-0166-2

[10] El Haddad, M., Moxham, L. and Broadbent, M. (2017) Graduate Nurse Practice Readiness: A Conceptual Understanding of an Age Old Debate. Collegian, 24, 391-396. https://doi.org/10.1016/j.colegn.2016.08.004

[11] Wolff, A.C., Regan, S., Pesut, B. and Black, J. (2010) Ready for What? An Exploration of the Meaning of New Graduate Nurses' Readiness for Practice. International Journal of Nursing Education Scholarship, 7, Article 7. https://doi.org/10.2202/1548-923X.1827

[12] Wright, A.P. (2014) Preparedness to Practice as Perceived by the Graduate Nurse. 
Doctoral Dissertation, Texas Woman's University, Denton. http://hdl.handle.net/11274/3693

[13] Nursing Council of New Zealand (2010) Education Programme Standards for the Registered Nurse Scope of Practice.

https://www.nursingcouncil.org.nz/Public/Education/Standards_for_programmes/ NCNZ/Education-section/Standards_for_programmes.aspx?hkey=52a51787-905a-4 81b-a4f7-4007742cbdbe

[14] Mackay, B. and Harding, T. (2018) An Exploratory Study on the Perceptions of Registered Nurses towards the Work Readiness of New Graduate Registered Nurses.

[15] Ministry of Justice (2019) Annual Suicide Statistics since 2011. https://coronialservices.justice.govt.nz/suicide/annual-suicide-statistics-since-2011/

[16] Davison, J., Mackay, B. and McGivern, M.J. (2017) The Potential of Simulation to Enhance Nursing Students' Preparation for Suicide Risk Assessment: A Review. Open Journal of Nursing, 7, 129-144. https://doi.org/10.4236/ojn.2017.72012

[17] Baldwin, A., Bentley, K., Langtree, T. and Mills, J. (2014) Achieving Graduate Outcomes in Undergraduate Nursing Education: Following the Yellow Brick Road. Nurse Education in Practice, 14, 9-11. https://doi.org/10.1016/j.nepr.2013.06.011

[18] Woods, C., West, C., Mills, J., Park, T., Southern, J. and Usher, K. (2015) Undergraduate Student Nurses' Self-Reported Preparedness for Practice. Collegian, 22, 359-368. https://doi.org/10.1016/j.colegn.2014.05.003

[19] Haggerty, C., Holloway, K. and Wilson D. (2013) How to Grow Our Own: An Evaluation of Preceptorship in New Zealand Graduate Nurse Programmes. Contemporary Nurse, 43, 162-171. https://doi.org/10.5172/conu.2013.43.2.162

[20] Gordon, C.J., Aggar, C., Williams, A.M., Walker, L., Willcock, S.M. and Bloomfield, J. (2014) A Transition Program to Primary Health Care for New Graduate Nurses: A Strategy towards Building a Sustainable Primary Health Care Nurse Workforce? BMC Nursing, 13, 34. https://doi.org/10.1186/s12912-014-0034-x

[21] Murray-Parahi, P., DiGiacomo, M., Jackson, D. and Davidson, P. (2016) New Graduate Registered Nurse Transition into Primary Health Care Roles: An Integrative Literature Review. Journal of Clinical Nursing, 25, 3084-3101. https://doi.org/10.1111/jocn.13297

[22] Ministry of Health (2018) Health Workforce New Zealand: Annual Report to the Minister of Health 1 July 2016 to 30 June 2017. Ministry of Health, Wellington. http://www.health.govt.nz

[23] Ministry of Health (2017) Recruitment of New Graduate Registered Nurses. https://www.health.govt.nz/our-work/nursing/developments-nursing/recruitmentnew-graduate-registered-nurses

[24] Wilkinson, J., Neville, S., Huntington, A. and Watson, P. (2016) Factors That Influence New Graduates' Preferences for Speciality Areas. Nursing Praxis in New Zealand, 32, 8-19.

[25] World Health Organization (2015) A Guide to Nursing and Midwifery Education Standards. http://applications.emro.who.int/dsaf/EMROPUB_2015_EN_1866.pdf

[26] Laari, L. and Dube, B.M. (2017) Nursing Students' Perceptions of Soft Skills Training in Ghana. Curationis, 40, e1-e5. https://doi.org/10.4102/curationis.v40i1.1677

[27] Laker, R. and Powell, J. (2011) The Differences between Hard and Soft Skills and Their Relative Impact on Training Transfer. Human Resource Development Quarterly, 22, 111-122. https://doi.org/10.1002/hrdq.20063

[28] Robles, M.M. (2012) Executive Perceptions of the Top 10 Soft Skills Needed in To- 
day's Workplace. Business and Professional Communication Quarterly, 75, 453-465. https://doi.org/10.1177/1080569912460400

[29] Ortiz, J. (2016) New Graduate Nurses' Experiences about Lack of Professional Confidence. Nurse Education in Practice, 19, 19-24.

https://doi.org/10.1016/j.nepr.2016.04.001

[30] Duchscher, J.E.B. (2009) Transition Shock: The Initial Stage of Role Adaptation for Newly Graduated Registered Nurses. Journal of Advanced Nursing, 65, 1103-1113. https://doi.org/10.1111/j.1365-2648.2008.04898.x

[31] Nielsen, A., Lasater, K. and Stock, M. (2016) A Framework to Support Preceptors' Evaluation and Development of New Nurses' Clinical Judgment. Nurse Education in Practice, 19, 84-90. https://doi.org/10.1016/j.nepr.2016.03.012 